Original Research

\title{
Analysis of Surface Water Areal changes using Remote Sensing Data
}

Heath Murray, Mehdi Khaki*

School of Engineering, University of Newcastle, Australia; E-Mails: Heath.Murray@uon.edu.au; mehdi.khaki@newcastle.edu.au

* Correspondence: Mehdi Khaki; E-Mail: mehdi.khaki@newcastle.edu.au

Academic Editor: Zed Rengel

Adv Environ Eng Res

2021, volume 2, issue 3

doi:10.21926/aeer.2103019
Received: October 23, 2020

Accepted: July 25, 2021

Published: July 29, 2021

\begin{abstract}
Inland water bodies are crucial for supporting human life in various parts of the world. Therefore, it is essential to accurately monitor its spatiotemporal variations for better water management. The main objective of this study is to investigate the application of remote sensing data for quantifying the surface area changes and the impact of climatological variabilities over Lakes Mead and Chapala. Historical time series of monthly surface area dynamics were developed using Landsat 1-8 scenes and the climate variability was analysed using evaporation rate and precipitation. Results show that estimated surface water changes from satellite data agree well with independent data. A significant decline in surface area of about $40 \%$ since 2000 was found over the Lake Mead region. The relationship between surface area, precipitation and evaporation indicate that climatological factors have contributed to the lake surface area reduction. Lake Chapala's surface area, on the other hand, has not fallen significantly despite negative trends in precipitation. It was found that human interactions with the lake are likely the main cause of surface area variations. The information about water surface area variation in this study is valuable for monitoring and characterising the predictability of water availability of the regions.
\end{abstract}

\section{Keywords}

Landsat; Lake Mead; Lake Chapala; time series analysis; surface area variation

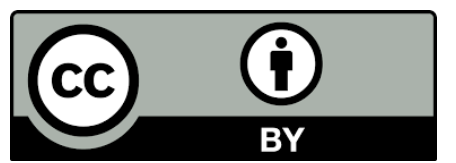

(C) 2021 by the author. This is an open access article distributed under the conditions of the Creative Commons by Attribution License, which permits unrestricted use, distribution, and reproduction in any medium or format, provided the original work is correctly cited. 


\section{Introduction}

Lakes are a major source of water for domestic and industrial uses and are vital for riparian zones which together support ecosystems and soil fertility. Water bodies have shown large surface area variations due to many factors including climate change and variability, and anthropogenic impacts such as municipal, irrigation and industrial water use (e.g., [1-4]). Where climatological factors significantly influence water volume, predictability metrics may be formed. For example, Lake Mead in Nevada-Arizona, U.S.A has net evaporation and precipitation fluctuations that are consistent with lake water volume variations [5]. For many lakes, the greatest threat to longevity is related to human factors as well as natural, as is the case for Lake Hulun in China [6]. For Haramaya Lake in Ethiopia, the main causes of surface area changes have been associated with the expansion of agriculture, poorly planned and managed human settlement and removal of vegetation [7]. The combination of these factors that affect surface water resources is expected to exacerbate water challenges making it increasingly difficult to meet water demand, leading to insufficient water for people and the environment. Thus, it is highly important to quantify historical changes in lake surface area in order to understand the sustainability of lakes for supply and demand.

Water storage can be regularly quantified from traditional in situ based measurements. However, the extent of available gauge stations is very limited and in many cases has significantly reduced in the past 30 to 40 years. For example, in the pan-Arctic basins of Canada and Russia, there was a $40 \%$ decline of in situ discharge gauges which severely limits the available information for computing long-term hydrological characteristics [8]. Satellite remote sensing, on the other hand, offers high spatial and temporal resolution data with vast coverage [9-11]. In the last few decades, remote sensing techniques have advanced into an alternative measure for long-term regular Global monitoring of water resources [3, 12-15]. They have been successfully applied to study water resources in different parts of the words at various scales, e.g., for rivers and lakes, basin-scale areas, and continental studies (e.g., [9, 16-21]).

The prime objective of this study is to use remote sensing data to (1) quantify water body surface area over Lake Mead (in the U.S.A) and Lake Chapala (Mexico) and (2) to investigate the impact of climatological variability on water surface area. To this end, the data collected by several is used to generate various time-series data. One of the main satellite platforms developed for such analyses is the Landsat satellite series, which ranges from 1972 to the present. Since 1 Oct 2008, these scenes are freely available from the United States Geological Survey (USGS), which allows access to the relevant timescale and historical duration free of cost [22]. Since Landsat-5, all Landsat missions are capable of a $30 \mathrm{~m}$ spatial resolution which allows for the extraction of smaller features compared to Moderate Imaging Spectroradiometer (MODIS) which has a maximum band spatial resolution of $250 \mathrm{~m}$ [3]. The Landsat program provides the longest-running timeline of Earth imagery that is superior to another space land motoring mission of Sentinel constellation with less than 5 years. Therefore, in this effort, Landsat imagery was the preferred choice to quantify historical variations in water body surface area.

To detect water body surface area from satellite imagery, image enhancement by spectral rationing is commonly used (e.g., [23-29]). Spectral rationing takes advantage of the contrast of two 
or more bands from a multispectral raster dataset. By comparing an image obtained in one spectral band to one obtained in a different spectral band, certain features may be enhanced. Many water indices such as Normalized Difference Water Index [30], Modified Normalized Difference Water Index [31] and New Water Index [24], have been used over the past few decades with some variations. Using Landsat imagery applied to the Qaidam Basin, Tibetan Plateau, NDWI was successful in water feature extraction as well as mapping the patterns of lakes and glaciers [28]. Another study by Schwatke et al. [3] developed an approach for the extraction of land-water masks using a combination of NWI, MNDWI and three other indices and applied it to 32 case studies. Motivated by the successful implementation of the approach, it was adopted here to derive surface water change time series using Landsat data.

In this study, surface water extent time-series developed, for the first time over Lake Mead and Lake Chapala using a scheme that comprises various steps including image enhancement and classification, surface water detection and area calculation, and analysing hydroclimate variability impacts. The first part of the process quantifies the surface area of the two study areas using 47 years of Landsat 1-8 scenes in monthly time steps. Once the water surface area time series were developed, waterbody surface area variations were compared with meteorological data time series specifically, evaporation and precipitation. From comparison with meteorological data, the connection between the water surface area variations and climate variabilities for each water body was assessed, which provides a greater understanding of the causality of the quantified water surface area variations.

The remainder of this study is organized as follows. The study areas are described in Section 2. The data and method used for the analysis of surface water areal changes are presented in Sections 3 and 4, respectively. The results are presented and discussed in Section 5. The study concludes with a summary of the main findings in Section 6.

\section{Study Areas}

The selected study areas, the Lake Mead region and Lake Chapala, are inland waters visible in Landsat scenes. The two sites have been chosen primarily based on their economic and ecological significance, along with technical considerations. The lakes have important roles in the local environment and climate, thus, essential to be monitored for sustained management.

\subsection{Lake Mead Region}

Lake Mead in Nevada-Arizona, U.S.A ( $36^{\circ} 08^{\prime} \mathrm{N}$ and $114^{\circ} 27^{\prime} \mathrm{W}$ ), is the largest reservoir by volume within the U.S. [32]. Lake Mead with an area of $640 \mathrm{~km}^{2}$ (approximately $180 \mathrm{~km}$ long and $68 \mathrm{~m}$ depth) is impounded by Hoover Dam and relies on the Colorado River as the main tributary. Downstream of Lake Mead, connected by the Colorado River is Lake Mohave which is impounded by Davis Dam. The first case study here analysed the surface area variation of both Lake Mead and Lake Mohave as one region shown in Figure 1. For simplicity, this will be referred to as Lake Mead Region hereafter. The surface water temperature of Lake Mead ranges from $11^{\circ} \mathrm{C}$ to $31^{\circ} \mathrm{C}$ over the course of a year [33], and the average annual precipitation from 1979 to 2018 was $244 \pm 91 \mathrm{~mm}$. Lake Mead is important economically as it supplies water to over 25 million people for household use, agriculture, and power generation across the U.S. Southwest [34] and supplying about $90 \%$ of municipal water needs in the Las Vegas Valley [33]. 


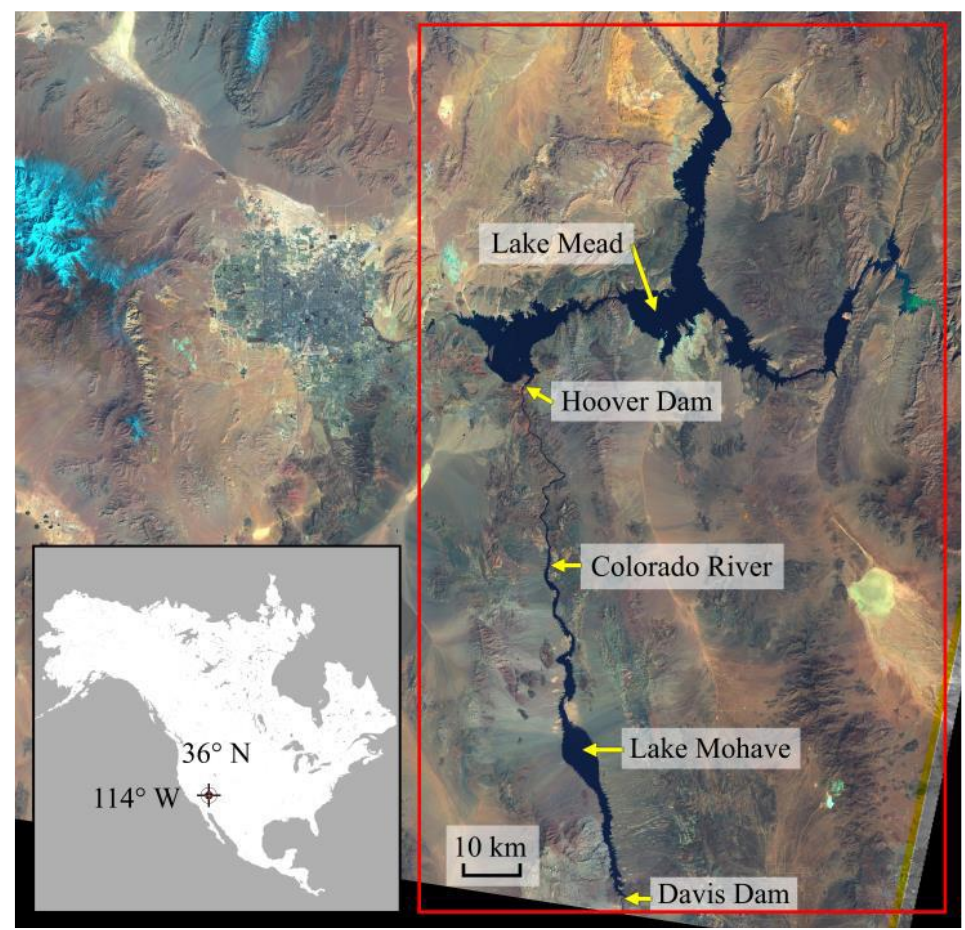

Figure 1 Showing Lake Mead region case study, with a red rectangular region defining study area.

\subsection{Lake Chapala}

Lake Chapala is located between Jalisco and Michoacán, Mexico $\left(20^{\circ} 15^{\prime} \mathrm{N}\right.$ and $\left.103^{\circ} 01^{\prime} \mathrm{W}\right)$. Lake Chapala is the largest natural lake in Mexico having an average depth of $6 \mathrm{~m}$, with a maximum depth near $11 \mathrm{~m} \mathrm{[35].} \mathrm{Lake} \mathrm{Chapala} \mathrm{(Figure} \mathrm{2)} \mathrm{covers} \mathrm{an} \mathrm{area} \mathrm{of} \mathrm{circa} 1161 \mathrm{~km}^{2}$; its length is over $79 \mathrm{~km}$ and has a width of circa $28 \mathrm{~km}$. The annual temperature of Lake Chapala ranges between $8^{\circ} \mathrm{C}$ and $30^{\circ} \mathrm{C}$ with annual precipitation of $750 \pm 195 \mathrm{~mm}$ [36]. Lake Chapala and water inbound from the Lerma River supply water for industry, drinking water and irrigation. On the riverside of Lake Chapala, considerable tourism, fishing, industrial, and agricultural activities are observed [35].

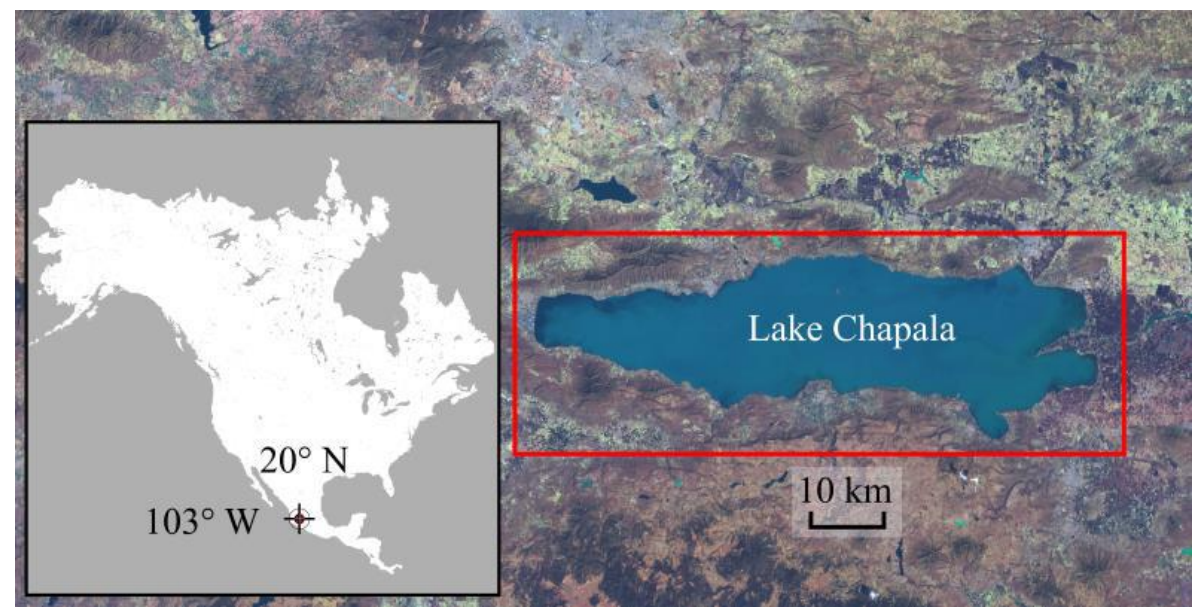

Figure 2 Showing Lake Chapala case study, with red rectangular region defining study area. 


\section{Data}

In this study, imagery from Landsat missions was used to compute a monthly surface area time series of the Lake Mead region and Lake Chapala. Evaporation and precipitation time series were then compared with surface area variations.

\subsection{Landsat Imagery}

Level 1 Landsat images from Landsat missions 1-8 available from 1972 were downloaded through the USGS website in 'EarthExplorer' and 'LandLook' viewers. Landsat imagery was manually downloaded each month from 1972 to 2020 within limitations of cloud obstructions and scene coverage. Data from the Landsat program has been recorded since 1972 using different image sensors with different pixel sizes and number of spectral bands. The first five Landsat missions used the Multi-Spectral Scanner (MSS) [37]. The data from the MSS was processed to a 60-metre pixel size [38]. The Thematic Mapper (TM) used in Landsat 4-7, had significant improvements to resolution and captured additional bands to the MSS [37]. The latest Landsat mission at the time of writing this journal (26 July 2021) is Landsat 8, which uses the Operational Land Imager (OLI). The OLI featured additional spectral bands and the data is scaled to 16-bit greyscale which is a large improvement over the preceding 8-bit Landsat imagery. The Landsat spectral bands, wavelength and pixel size for all Landsat missions used in this project is presented in Table 1.

Table 1 Landsat missions with relevant details including pixel size, band numbers and wavelength [38].

\begin{tabular}{|c|c|c|c|c|c|c|c|c|c|c|}
\hline \multirow{2}{*}{$\begin{array}{l}\text { Spectral } \\
\text { Band }\end{array}$} & $\begin{array}{l}\text { Landsat } \\
\text { (MSS) }\end{array}$ & $1-5$ & \multicolumn{2}{|c|}{ Landsat 4 (TM) } & \multicolumn{2}{|c|}{ Landsat 5 (TM) } & \multicolumn{2}{|c|}{ Landsat 7 (TM) } & \multicolumn{2}{|c|}{ Landsat 8 (OLI) } \\
\hline & $\begin{array}{l}\text { Wavel } \\
\text { ength } \\
(\mu \mathrm{m})\end{array}$ & $\begin{array}{l}\text { Pixel } \\
\text { Size } \\
(p x)\end{array}$ & $\begin{array}{l}\text { Wavele } \\
\text { ngth } \\
(\mu \mathrm{m})\end{array}$ & $\begin{array}{l}\text { Pixel } \\
\text { Size } \\
(\mathrm{px}) \\
\end{array}$ & $\begin{array}{l}\text { Wavele } \\
\text { ngth } \\
(\mu \mathrm{m})\end{array}$ & $\begin{array}{l}\text { Pixel } \\
\text { Size } \\
(p x)\end{array}$ & $\begin{array}{l}\text { Wavele } \\
\text { ngth } \\
(\mu \mathrm{m})\end{array}$ & $\begin{array}{l}\text { Pixel } \\
\text { Size } \\
(p x)\end{array}$ & $\begin{array}{l}\text { Wavele } \\
\text { ngth } \\
(\mu \mathrm{m})\end{array}$ & $\begin{array}{l}\text { Pixel } \\
\text { Size } \\
(p x) \\
\end{array}$ \\
\hline Band 1 & $\mathrm{n} / \mathrm{a}$ & $\mathrm{n} / \mathrm{a}$ & $\begin{array}{l}0.45- \\
0.52\end{array}$ & 30 & $\begin{array}{l}0.45- \\
0.52\end{array}$ & 30 & $\begin{array}{l}0.45- \\
0.52\end{array}$ & 30 & $\begin{array}{l}0.43- \\
0.45\end{array}$ & 30 \\
\hline Band 2 & $\mathrm{n} / \mathrm{a}$ & $\mathrm{n} / \mathrm{a}$ & $\begin{array}{l}0.52- \\
0.60\end{array}$ & 30 & $\begin{array}{l}0.52- \\
0.60\end{array}$ & 30 & $\begin{array}{l}0.52- \\
0.60\end{array}$ & 30 & $\begin{array}{l}0.450- \\
0.51\end{array}$ & 30 \\
\hline Band 3 & $\mathrm{n} / \mathrm{a}$ & $\mathrm{n} / \mathrm{a}$ & $\begin{array}{l}0.63- \\
0.69\end{array}$ & 30 & $\begin{array}{l}0.63- \\
0.69\end{array}$ & 30 & $\begin{array}{l}0.63- \\
0.69\end{array}$ & 30 & $\begin{array}{l}0.53- \\
0.59\end{array}$ & 30 \\
\hline Band 4 & $\begin{array}{ll}0.5 & \text { to } \\
0.6 & \end{array}$ & 60 & $\begin{array}{l}0.76- \\
0.90\end{array}$ & 30 & $\begin{array}{l}0.76- \\
0.90\end{array}$ & 30 & $\begin{array}{l}0.77- \\
0.90\end{array}$ & 30 & $\begin{array}{l}0.64- \\
0.67\end{array}$ & 30 \\
\hline Band 5 & $\begin{array}{ll}0.6 & \text { to } \\
0.7 & \end{array}$ & 60 & $\begin{array}{l}1.55- \\
1.75\end{array}$ & 30 & $\begin{array}{l}1.55- \\
1.75\end{array}$ & 30 & $\begin{array}{l}1.55- \\
1.75\end{array}$ & 30 & $\begin{array}{l}0.85- \\
0.88\end{array}$ & 30 \\
\hline Band 6 & $\begin{array}{ll}0.7 & \text { to } \\
0.8 & \end{array}$ & 60 & $\begin{array}{l}10.40- \\
12.50\end{array}$ & 120 & $\begin{array}{l}10.40- \\
12.50\end{array}$ & 120 & $\begin{array}{l}10.40- \\
12.50\end{array}$ & 60 & $\begin{array}{l}1.57- \\
1.65\end{array}$ & 30 \\
\hline Band 7 & $\begin{array}{ll}0.8 & \text { to } \\
1.1 & \end{array}$ & 60 & $\begin{array}{l}2.08- \\
2.35\end{array}$ & 30 & $\begin{array}{l}2.08- \\
2.35\end{array}$ & 30 & $\begin{array}{l}2.08- \\
2.35\end{array}$ & 30 & $\begin{array}{l}2.11- \\
2.29\end{array}$ & 30 \\
\hline Band 8 & $\mathrm{n} / \mathrm{a}$ & $\mathrm{n} / \mathrm{a}$ & $\mathrm{n} / \mathrm{a}$ & $\mathrm{n} / \mathrm{a}$ & $\mathrm{n} / \mathrm{a}$ & $\mathrm{n} / \mathrm{a}$ & $\begin{array}{l}0.52- \\
0.90\end{array}$ & 15 & $\begin{array}{l}0.50- \\
0.68\end{array}$ & 15 \\
\hline
\end{tabular}




\begin{tabular}{|c|c|c|c|c|c|c|c|c|c|c|}
\hline Band 9 & $\mathrm{n} / \mathrm{a}$ & $\mathrm{n} / \mathrm{a}$ & $\mathrm{n} / \mathrm{a}$ & $n / a$ & $\mathrm{n} / \mathrm{a}$ & $\mathrm{n} / \mathrm{a}$ & $\mathrm{n} / \mathrm{a}$ & $\mathrm{n} / \mathrm{a}$ & $\begin{array}{l}1.36- \\
1.38\end{array}$ & 30 \\
\hline Band 10 & $\mathrm{n} / \mathrm{a}$ & $\mathrm{n} / \mathrm{a}$ & $\mathrm{n} / \mathrm{a}$ & $n / a$ & $\mathrm{n} / \mathrm{a}$ & $\mathrm{n} / \mathrm{a}$ & $\mathrm{n} / \mathrm{a}$ & $\mathrm{n} / \mathrm{a}$ & $\begin{array}{l}10.6- \\
11.19\end{array}$ & 100 \\
\hline Band 11 & $\mathrm{n} / \mathrm{a}$ & $\mathrm{n} / \mathrm{a}$ & $n / a$ & $n / a$ & $\mathrm{n} / \mathrm{a}$ & $\mathrm{n} / \mathrm{a}$ & $\mathrm{n} / \mathrm{a}$ & $\mathrm{n} / \mathrm{a}$ & $\begin{array}{l}11.5- \\
12.51\end{array}$ & 100 \\
\hline
\end{tabular}

Note: Values highlighted in grey indicate spectral bands not used for water classification in this study.

\subsection{Evaporation and Precipitation Data}

The effects of climatological changes in evaporation and precipitation on surface area variation of the Lake Mead region and Lake Chapala was investigated. Evaporation and precipitation data were obtained at a monthly temporal resolution in the Lake Mead region and Lake Chapala from ERA5-Land monthly data (by the European Centre for Medium-Range Weather Forecasts (ECMWF)). The spatial resolution of the dataset is $0.1^{\circ} \times 0.1^{\circ}$ grid-distributed, which was averaged over the lakes for comparison with the surface extent time series.

\subsection{Validation Data}

The surface area time series data determined in this study was validated against independent time series data obtained from the Database for Hydrological Time Series of Inland Waters (DAHITI: https://dahiti.dgfi.tum.de/en/).

Volume variations time series of Lake Mead between 1984 to 2020 derived using water levels from satellite altimetry was downloaded from DAHITI [39]. While in this study, the Lake Mead region included Lake Mead and Lake Mohave, the Lake Mead volume variation alone is expected to show a high correlation with the Lake Mead region. Lakes connected by the Colorado River have been shown to mirror volume variations, such as Lake Mead and Lake Powell [40]. Therefore, as Lake Mohave and Lake Mead are part of the Colorado River, using correlation analysis between Lake Mead region surface area variations and Lake Mead volume variations can provide insights into the performance of the proposed approach in accurately determining surface area variations.

Water level time series acquired from satellite altimetry over Lake Chapala for the years 2002 to 2010 and 2013 to 2020 was downloaded from DAHITI [41]. Correlation analysis was again applied between Lake Chapala water level time series and the respective surface area time series to evaluate the results.

\section{Method}

\subsection{Image Processing}

The following general workflow (Figure 3) was performed to calculate the water surface area from Landsat imagery. The methodology of calculating the water surface area of the Lake Mead region differed from Lake Chapala by image enhancement. The main reason for this refers to the regions' different topography and land cover. The availability of snow and shadowed regions from mountains around Lake Mead makes it difficult to apply a similar enhancement strategy over Lake 
Mead as that of Lake Chapala. Therefore, Landsat images used to classify Lake Chapala were enhanced using spectral rationing, whereas to classify water in the Lake Mead region a threshold was applied directly to multiple raw image bands (see details in Sections 4.1.1-4.1.3).

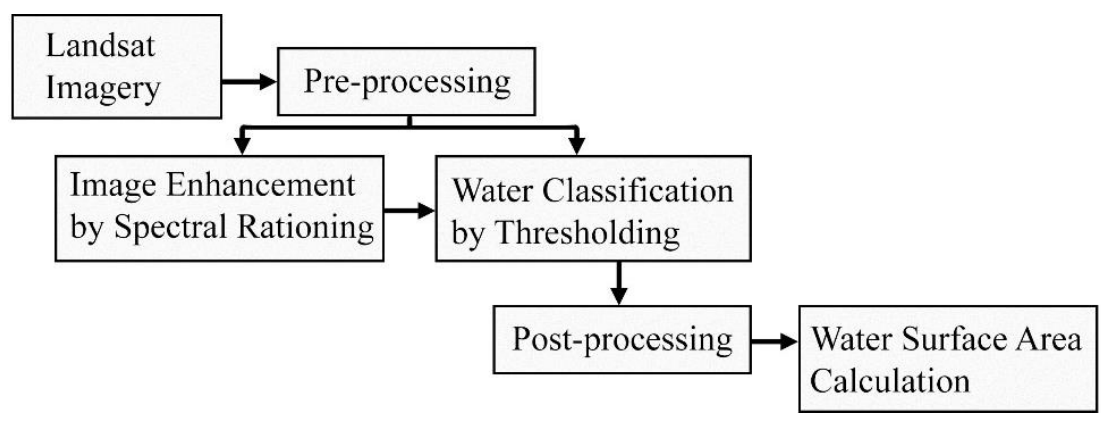

Figure 3 Schematic of the water classification method used in this study. The Landsat data are first pre-processed using the Image Stitching algorithm. The results are then enhanced by Spectral Rationing and Thresholding methods. Afterwards, a postprocessing step is applied to eliminate shadows from the images. These are ultimately used to derive the area of surface water within the case studies.

\subsubsection{Pre-Processing}

Image Stitching Using Point Feature Matching. For many months in the Landsat imagery time series, two Landsat images were required, which should be merged for full coverage of the water body being analysed (see, e.g., $[20,29])$. In these months, two images within the same month were stitched together using an object feature detection and matching scheme [42]. Using point feature matching the position of one image was identified in the second image. With the position of overlap known, the two images were stitched to create an image composite that covered the whole water body.

Rectification of Landsat-7 SLC error. On May 31, 2003, the Landsat-7 Scan Line Corrector (SLC) failed which resulted in diagonal zig-zagged black lines covering $22 \%$ of every scene. This was addressed by interpolating nearby values to replace missing values in sampled data.

\subsubsection{Image Enhancement}

For the water classification of Lake Chapala, image enhancement by spectral rationing was used. This was essential to achieve a better contrast between water and land. The spectral ratio was calculated by subtracting an infrared wavelength band by the shortest visible wavelength band. For example, for Landsat-8 Eq. 1 displays how two spectral bands were used to calculate the spectral ratio.

$$
\text { Spectral Ratio L08 }=(\text { Band } 1-\text { Band } 7) /(\text { Band } 1+\text { Band } 7)
$$

where,

Band $1=$ Visible band with wavelength $0.43-0.45 \mu \mathrm{m}$,

Band 7 = Short Wave Infrared with wavelength $2.11-2.29 \mu \mathrm{m}$. 
Water was then segmented from images by thresholding to create binarised images containing water as white pixels and other features black. The raw Landsat images in Figure 4 (a) and Figure 4 (b) were enhanced using Eq 1 over Lake Chapala. A threshold value between 0 and 1 was chosen to separate water from other features. The enhanced image in Figure 4 (c) shows water occupied the upper pixel intensity range. The threshold value of 0.984 was chosen due to its better outcomes using these image bands to produce the classified binary image in Figure 4 (d). The final result of water classification is shown in Figure 4 (e) with post-processing applied as per Section 4.1.3.
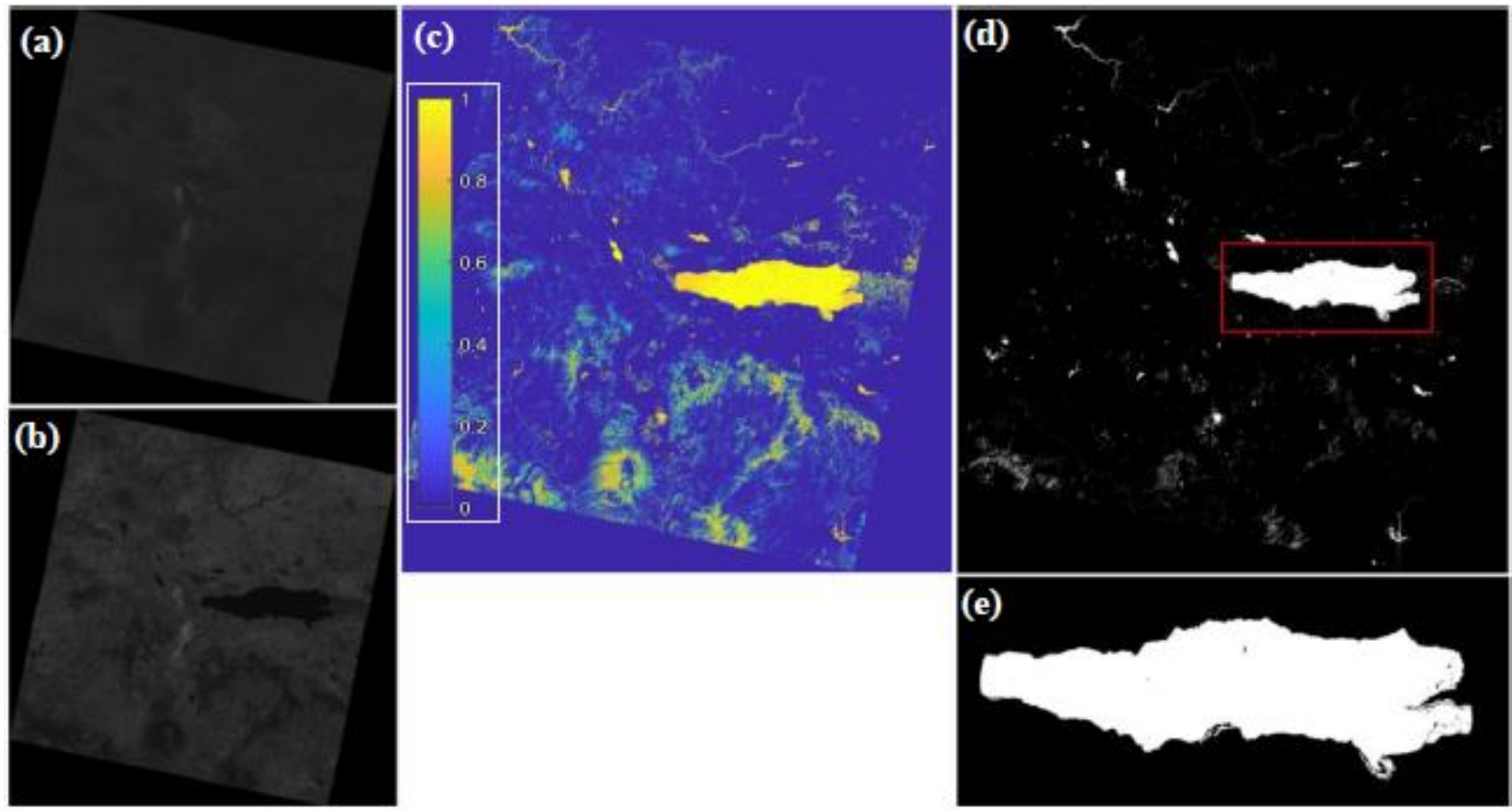

Figure 4 (a) Landsat-8 Band-1 image. (b) Landsat-8 Band-7 image. (c) Showing enhanced image of Lake Chapala. (d) Binary image created from a threshold of 0.984. (e) Final classified image of Lake Chapala after post-processing. Landsat-8 images from 25 March 2020 and bands 1 and 7 reflect visible and shortwave IR.

The water classification method applied to the Lake Mead region did not use image enhancement. Accurate segmentation of water from other features was difficult with snow and shadowed regions from mountains around Lake Mead occupying similar intensity ranges to water. The difficulty of water classification was further increased with the region having both deep and shallow water, which can increase the pixel intensity range of water. To classify water from Landsat images in the Lake Mead region, threshold values were applied based on trial and error using the histograms of Landsat images. An example of water classification applied to Landsat-8 bands is shown in Figure 5 . A pixel intensity threshold was applied to Band-7 and from the band ratios, a threshold was also applied to Bands 1-6 to produce the binary image shown in Figure 5(b). The final result of water classification is shown in Figure 5(c) with post-processing applied as per Section 4.1.3. 


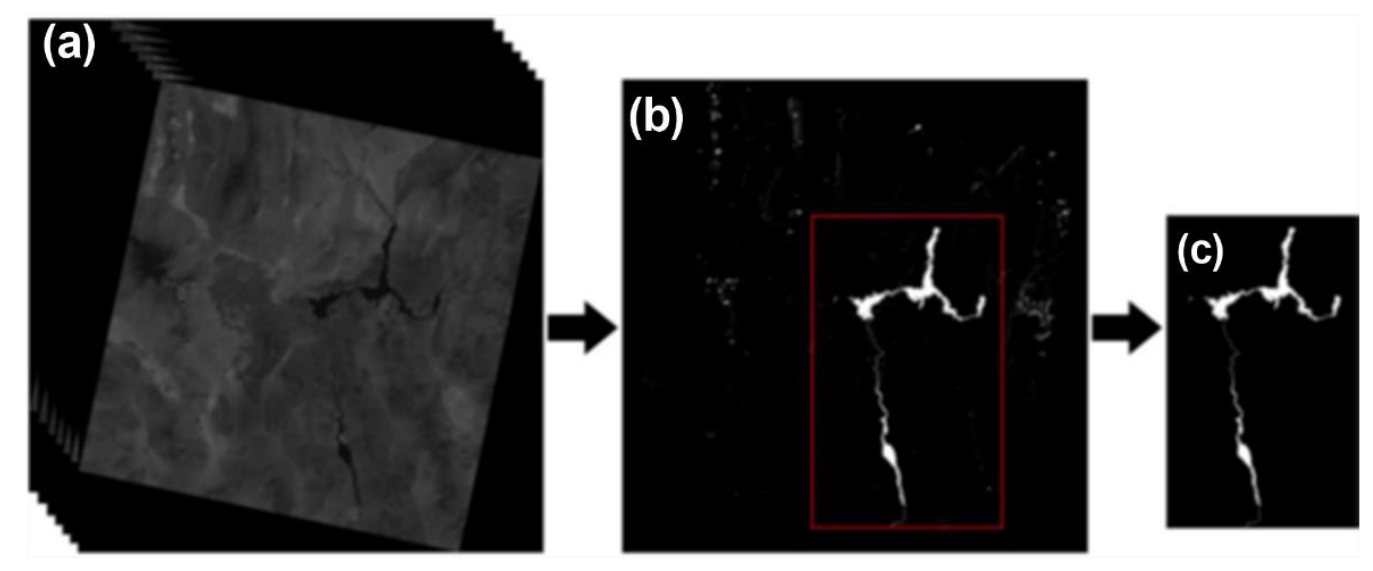

Figure 5 (a) Landsat-8 Bands 1-7 used for water classification. (b) Binary image created from threshold values. (c) Final classified Lake Mead region with post-processing applied.

\subsubsection{Post Processing}

After water classification, inevitably there were localised misclassified pixel areas. It was found that areas commonly misclassified were due to shadows of clouds and valleys. Shadows made by mountains and overshadow from cloud cover often shared the same pixel intensity range as water. For example, Figure 6 shows misclassified regions up to 40 pixels in area, resultant of mountain shadow. The segregated misclassified regions were removed (see also $[21,26]$ ). This was done by removing all objects in the classified binary image less than a specified area. The specified area was dependant on the size of misclassified objects which ranged from circa 100-2000 pixels in Landsat images with $30 \mathrm{~m}$ pixel size.

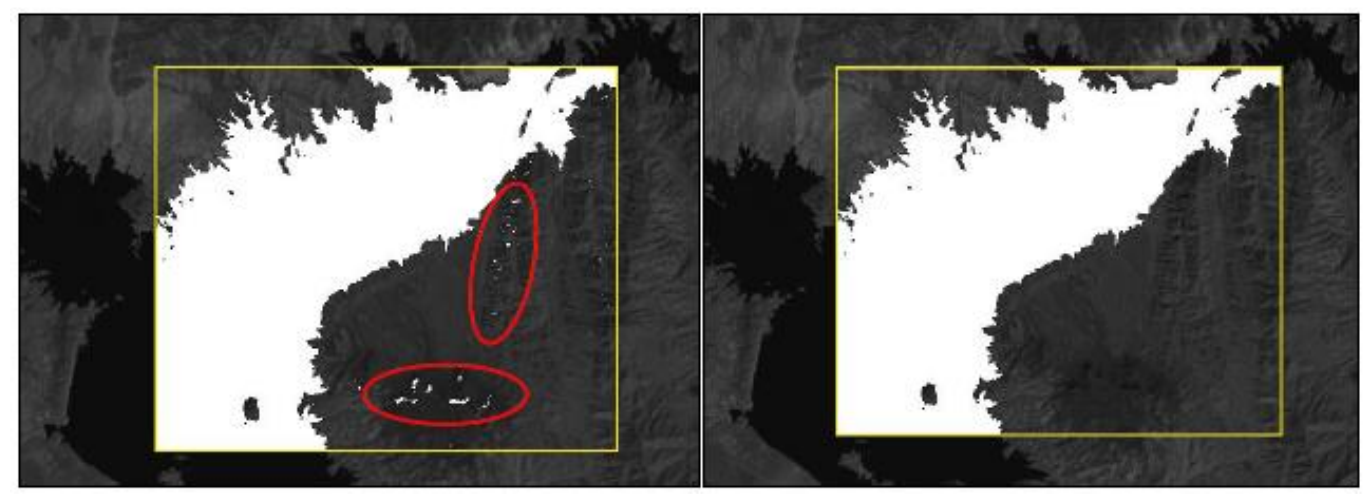

Figure 6 Classified binary image overlayed on Landsat image within the yellow rectangular region, showing misclassified pixels outlined in red (left) and image noise removed (right).

\subsection{Surface Area Calculation}

The area of the water body was then calculated using Eq. 2 from the total number of white pixels classified in the binary image. 


$$
\text { Water Body Area }=N \times S^{2} \text {, }
$$

where $N$ is the number of white pixels and $S$ is the pixel size. The pixel size in Landsat images used for water classification was either $30 \mathrm{~m}$ or $60 \mathrm{~m}$, depending on Landsat mission and image band as shown in Table 1.

\subsection{Climate Variability}

To investigate the impact of climate variability on the lakes surface water changes, ERA5-Land monthly data was used. The gridded data with $0.1^{\circ} \times 0.1^{\circ}$ spatial resolution were used for the same period of Landsat products. For every month, the gridded precipitation and evaporation products were averaged over the lakes, which led to a monthly time series of precipitation and evaporation. These were compared to surface area change time series calculated from Landsat visually and also using the correlation analysis.

\subsection{Correlation Analysis}

The cross-correlation was calculated to derive the degree to which two series are correlated considering a potential existence delay between time series. For this, the cross-correlation $(R)$ of two series $x_{n}$ and $y_{n}(\mathrm{n}=0,1,2 \ldots \mathrm{N}-1)$ with delay $\mathrm{d}$ is given by,

$$
R(d)=\frac{\sum_{n}\left[\left(x_{n}-\mu_{x}\right) *\left(y_{n-d}-\mu_{y}\right)\right]}{\sqrt{\sum_{n}\left(x_{n}-\mu_{x}\right)^{2}} \sqrt{\sum_{n}\left(y_{n-d}-\mu_{y}\right)^{2}}}
$$

where $\mu_{x}$ and $\mu_{y}$ are the means of $x_{n}$ and $y_{n}$, respectively. If the above is computed for all delays then $\mathrm{d}=0,1,2 \ldots \mathrm{N}-1$ and a cross-correlation series of twice the length as the original series is calculated (see details in [43]). Here, $x_{n}$ time series represent surface water area changes and $y_{n}$ refer to different variables such as precipitation and evaporation.

\subsection{Trend Analysis}

To better explore the time series variations, specifically for surface water area changes, we estimated trends at different time spans within time series. To this end, the time periods with considerable trends were identified visually and then a 1-degree line was fitted to each period. This was done by calculating $\mathrm{a}$ and $\mathrm{b}$ in a linear equation $z=a t+b$, with $t$ being the time and $z$ corresponding values of the variable (e.g., surface area). a and b can be calculated by solving the following matrix equation.

$$
\left(\begin{array}{cc}
t_{1} & 1 \\
t_{2} & 1 \\
\vdots & \vdots \\
t_{N} & 1
\end{array}\right)\left(\begin{array}{l}
a \\
b
\end{array}\right)=\left(\begin{array}{c}
z_{1} \\
z_{2} \\
\vdots \\
z_{N}
\end{array}\right)
$$




\section{Results}

The surface areas of the Lake Mead region and Lake Chapala were calculated at a monthly temporal resolution from the Landsat images. Some intermediate months along the surface area time series were excluded due to excessive cloud cover or lack of image availability. As a result, there were gaps in the discrete time series of surface area. The very limited missing data was then linearly interpolated. Comparison against validation data indicated that the applied linear interpolation did not degrade the entre water surface area results.

\subsection{Lake Mead Region Surface Area}

The monthly surface area variation of the Lake Mead region is shown in Figure 7. Indicated by the high water surface area from 1972 to 1988, the Lake Mead region was at high capacity. From 1988 to 1992 a surface area decline occurred circa 17\% which was recovered between 1993 and 1998. Significant surface area loss occurred from 2000 to 2011 of circa $40 \%$ due to extended drought and increasing water demands by population growth [32]. NASA Earth Observatory [44] reported an above-average inflow of melting snow from the Rocky Mountains from late 2010 to early 2012. The inflow of melting snow and high rainfall in late 2010 to early 2011, caused an increase in water surface area in 2011. The surface area then reduced in 2014, and since 2015 the Lake Mead region surface area has varied between circa $420 \mathrm{~km}^{2}$ to $430 \mathrm{~km}^{2}$.

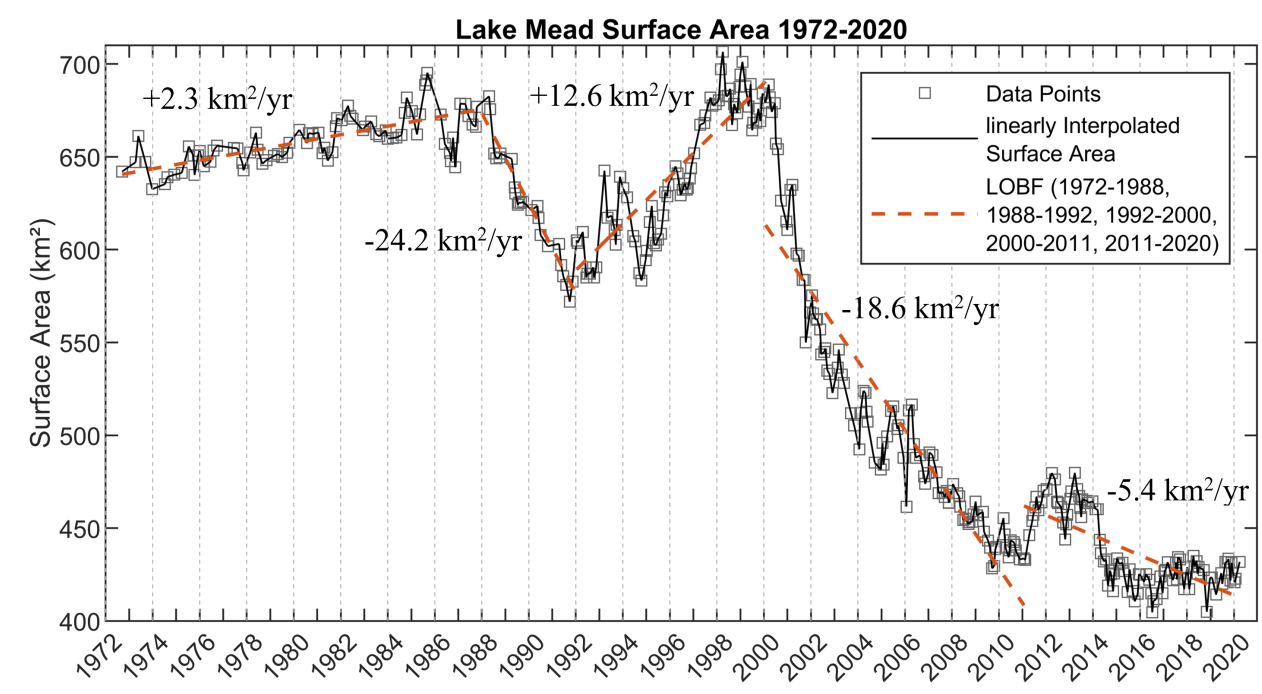

Figure 7 Surface area of the Lake Mead region from September 1972 to January 2020.

\subsection{Lake Chapala Surface Area}

The monthly surface area variation of Lake Chapala using Landsat imagery between 1973 and 2020 is shown in Figure 8. Before 1993, the availability of Landsat imagery of Lake Chapala was low mainly due to cloud cover obstructions, resulting in long periods void of surface area data. A negative downward trend of water surface area in Lake Chapala is visible between 1993 and 2003 as shown in Figure 8. The downward trends in water volume in Lake Chapala from 1979 to 2001 has been due to excessive water extraction for agricultural and municipal needs [45]. Lake Chapala was named Threatened Lake of the Year in 2004 by the Global Nature Fund. This, along with the applied 
new policy to control water withdrawals from the lake has helped to rebound the water surface area since 2004. The effect can be clearly seen from the results of the water surface area shown in Figure 8 and further justified in Figure 9.

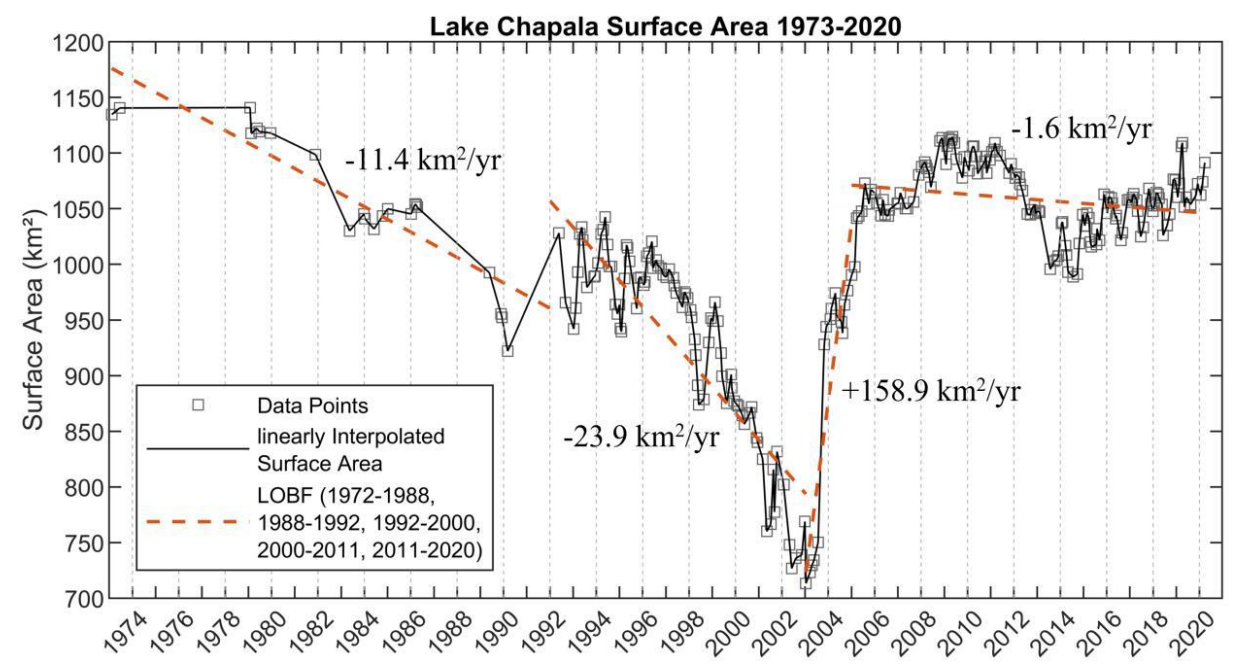

Figure 8 Lake Chapala surface area determined from Landsat imagery from February 1973 to March 2020.
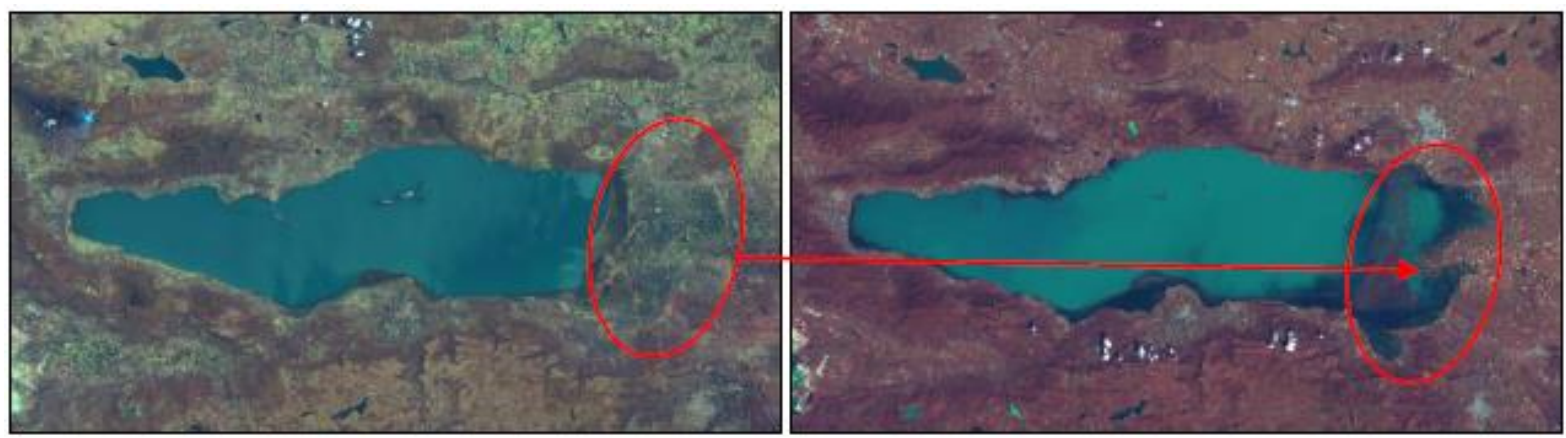

Figure 9 Showing change in surface area $\left(\right.$ circa $180 \mathrm{~km}^{2}$ ) of Lake Chapala from May to October 2003.

Lake Chapala has a shallow depth allowing high variations in surface area between months to occur. By 2003 Lake Chapala had reduced water volume to circa $20 \%$ of its capacity [45]. Between May 2003 and October 2003 heavy rainfall substantially increased the water volume in Lake Chapala. The sharp increase in surface area between May 2003 and October 2003 seen in Figure 8 is shown by Landsat-7 false colour composites in Figure 9.

\subsection{Climate Variability Impacts}

The cause of surface area variations was investigated through correlating surface area variation with evaporation and precipitation. The cross-correlation (determined between -1.0 and +1.0 ) between discrete-time series was calculated to measure maximum similarity at a lagged position. 


\subsubsection{Lake Mead Region}

For the Lake Mead region, the correlation coefficient between evaporation and surface area was 0.76. This shows a good agreement between the two time series over the study area. The monthly surface area was plotted with precipitation and evaporation from ERA5-Land monthly data to examine comparison with water surface area, precipitation and evaporation fluctuations in the Lake Mead region. Both evaporation and precipitation show negative downward trends. From 1979 to 2019, from linear approximation, precipitation trends downward circa $0.2 \mathrm{~mm}$ per year. There was 19\% less precipitation and 13\% less evaporation from 1999-to-2014 than from 1984-to-1999 which has contributed to the decline in water surface area shown in Figure 10. This shows that climate variabilities have the biggest contribution to the lake's water change. A high correlation value between the surface area change and evaporation time series, as well as with precipitation (0.65) also indicate this. It is found that the water area changes and trends follow the evaporation and precipitation pattern demonstrating the major role of climate over the region.

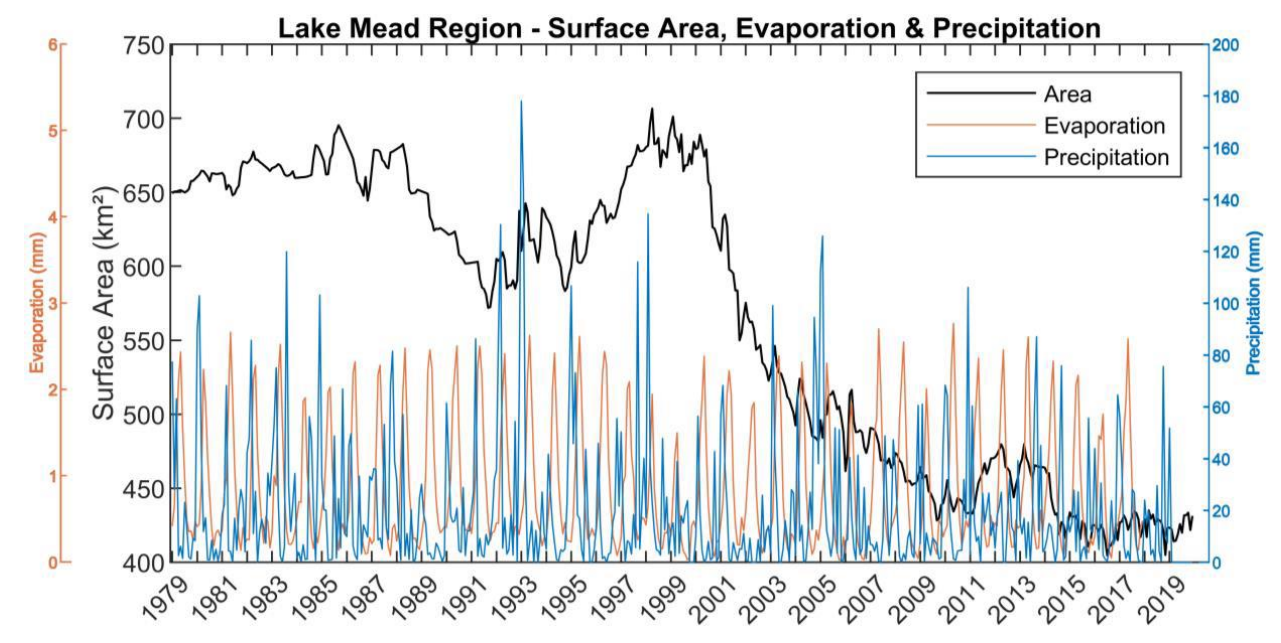

Figure 10 Showing the surface area precipitation and evaporation variations in the Lake Mead region.

\subsubsection{Lake Chapala}

For Lake Chapala, the correlation coefficient between evaporation and surface area was 0.86 and between evaporation and surface area was 0.62 , which indicate that surface area variations largely follow the climate variability between 1993 and 2019. The monthly surface area was plotted with precipitation and evaporation from ERA5-Land monthly data to examine the reasons for water surface area fluctuations of Lake Chapala (Figure 11). The spikes in evaporation correspond to troughs in surface area which supports the strong numerical correlation, thus, the great impact of climate variability of the lake's area changes. From linear approximation, precipitation trends downward circa $0.85 \mathrm{~mm}$ per year. However, the surface area of Lake Chapala does not reflect the negative trend in precipitation as shown in Figure 11. As explained, this can be explained by the impact of water management policies, especially after 2003 (cf. Section 5.2). Similar impacts can be observed prior to 2003, where a considerable negative trend in surface area changes is less pronounced in precipitation. Such an anthropogenic impact can clearly be seen after 2003 when the lake's area increases significantly. The effect, however, declines over time from the better match 
between the precipitation time series and that of surface area. It can also be seen that precipitation rises in 2009 and 2013 cause water area increases. Overall, it is found that in addition to the climate, anthropogenic impacts are also important players over Lake Chapala influencing its area on various occasions, e.g., before and after 2003.

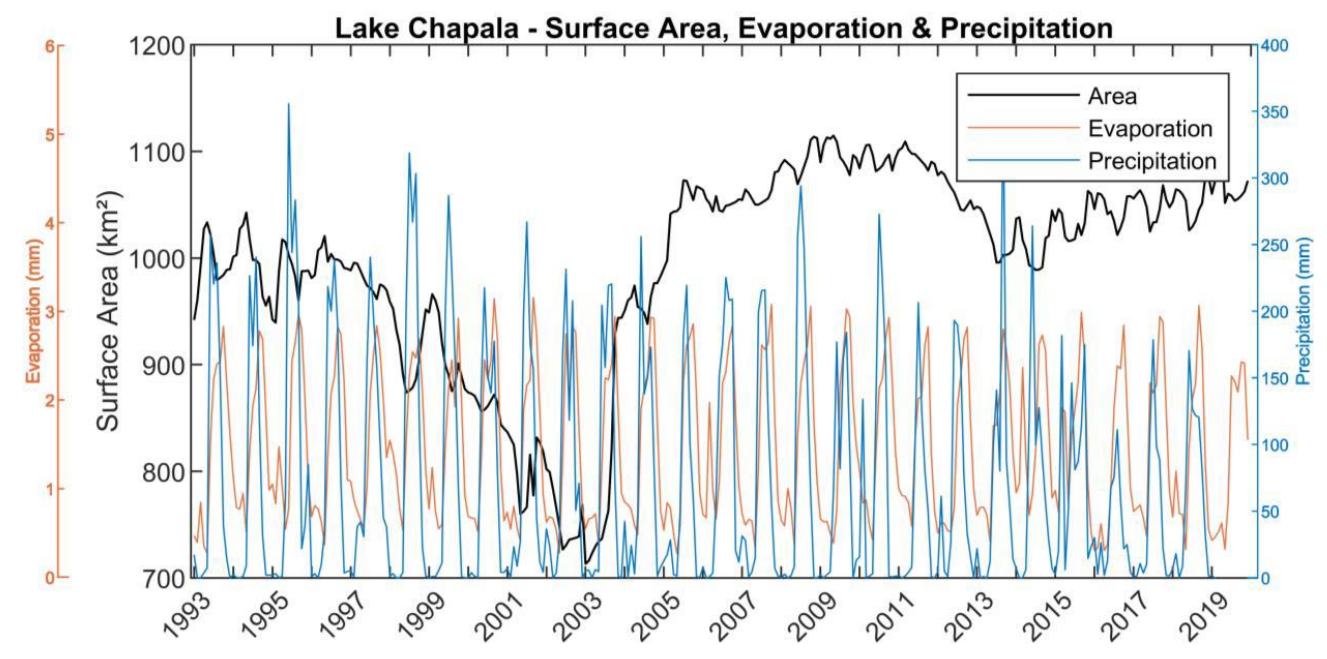

Figure 11 Showing the surface area precipitation and evaporation variations in Lake Chapala.

\subsection{Results Validation}

The surface area variation time series of the Lake Mead region and Lake Chapala was evaluated against hydrological time series data. To this end, independent time series data of water level and volume variations obtained from DAHITI were used. These observations were acquired at a monthly timescale. Correlation analysis was then applied to calculate correlation values. Gaps in the discrete hydrological time series data were again linearly interpolated.

\subsubsection{Lake Mead Region}

Correlation between the Lake Mead region surface area variations and Lake Mead volume variations (derived from DAHITI) was calculated for the period of 1984 to 2020 . The correlation coefficient of the time series shown in Figure 12 for the Lake Mead region surface area variations (blue) with Lake Mead volume variations (orange) was 0.89 . Note that this is the maximum calculated correlation value without the impact of lag between the two times series (lag calculated to 1 month). The surface area variation of the Lake Mead region included Lake Mead and Lake Mohave, while the volume variation time series included only Lake Mead. Because lakes connected by the Colorado River tend to show mirrored volume variations, the peaks of water volume and surface area tend to correspond. It can be seen from Figure 12, between 1986 and 1990 the peaks of surface area variation occur after the volume variations, while between 2007 and 2010 the peaks coincide. Despite small differences between the two time series that are expected to arise from comparing two different study areas, the two time series achieved a high correlation of 0.89 . This shows a good performance of the applied approach for calculating surface water areas. 


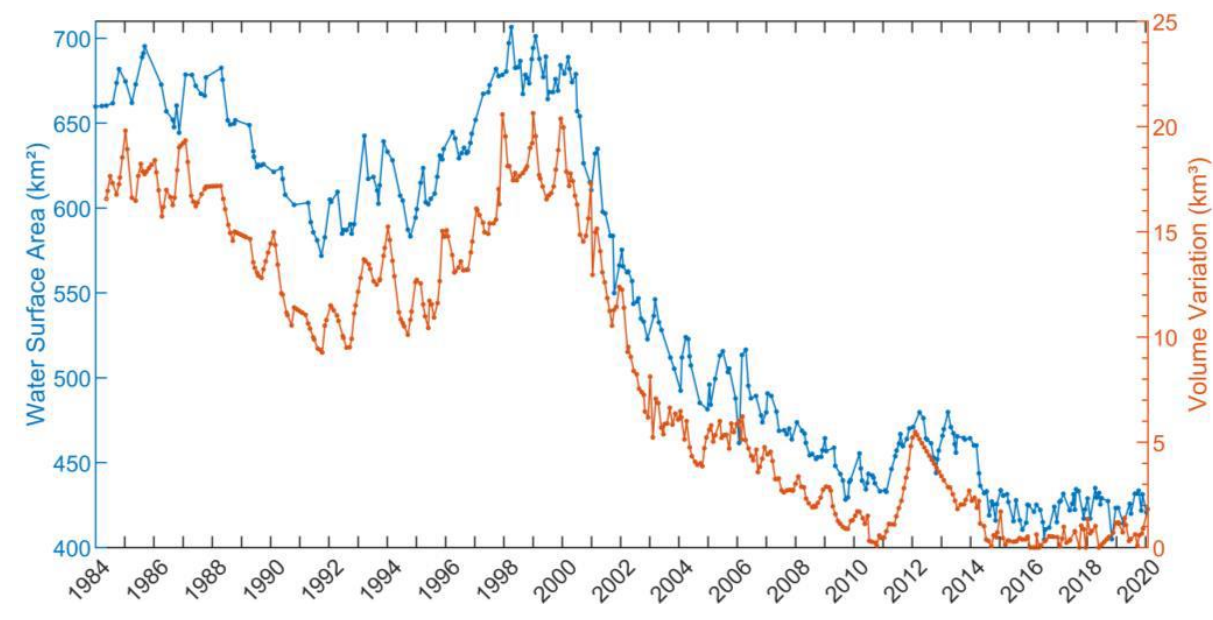

Figure 12 Lake Mead region surface area variations (blue) and Lake Mead volume variations (orange).

\subsubsection{Lake Chapala}

Correlation between Lake Chapala surface area variations and Lake Chapala water depth variations were calculated separately for the periods of 2002 to 2010 and 2013 to 2020 . This is due to the discrepancy in the water depth observations derived from DAHITI. The average correlation for the two periods of 2002 to 2010 and 2013 to 2020 was 0.97 (with 1 month lag). The high correlation coefficient is consistent with variations of the two time series shown in Figure 13. Apart from one low water depth reading in December 2004, water depth readings show variations that closely resemble surface area variations. This further proves the accuracy of the applied methodology for measuring the variations of lakes' surface area even at a small scale in the presence of images noises (cf. Section 4).

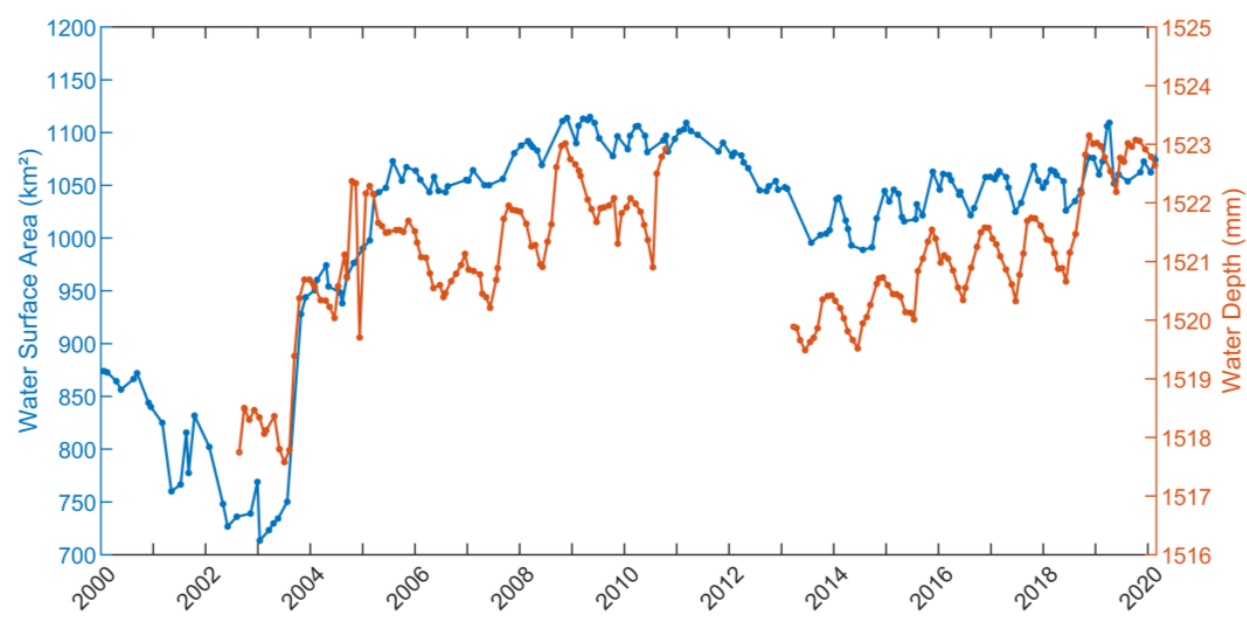

Figure 13 Lake Chapala surface area variations (blue) and Lake Chapala depth variations as Global MSL (orange).

\section{Conclusion}

With satellite imagery providing long-term time series free of cost, there is an opportunity to calculate predictability metrics of water body surface area changes. From the analysis in this study, 
both the Lake Mead region and Lake Chapala show large surface area variations between 1972 and 2020. The methodology of water classification used in this study was shown to be successful with image enhancement. The time series of surface area variations for both sites were validated against independent time series data. The surface area variations determined in this study had an average 0.92 correlation with the independent data used for validation. Using the generated water surface area time series, we were able to detect multiple trends and strong anomalies over the lakes. It was also found that climatological variability impacts were a significant cause for water surface area variations in both study areas. The data correlation of water surface area with evaporation and precipitation extracted meaningful information regarding the degree of predictability of water surface area changes. The water surface area variation quantified in this project can be used with water depth values to estimate water volume changes by Landsat-bathymetry-volume or altimetryLandsat-volume methods. Furthermore, with the new Sentinel-2 Earth observatory missions and future Landsat missions the temporal and spatial resolution of remote sensing data available will improve surface area estimations and allow for better study of water surface area variability on Earth.

\section{Author Contributions}

M. Khaki and H. Murray conceived the presented study. H. Murray acquired data and implemented the numerical analysis. M. Khaki assisted with the data and method. H. Murray prepared the initial draft of the manuscript, which was improved due to contributions of M. Khaki.

\section{Competing Interests}

The authors have declared that no competing interests exist.

\section{References}

1. Bates BC, Kundzewicz ZW, Wu SH, Palutikof J. Climate change and water: Technical Paper VI. Geneva, Switzerland: IPCC; 2008. Available from: https://archive.ipcc.ch/pdf/technicalpapers/climate-change-water-en.pdf.

2. You QL, Min JZ, Kang SC, Pepin N. Poleward expansion of the tropical belt derived from upper tropospheric water vapour. Int J Climatol. 2015; 35: 2237-2242.

3. Schwatke C, Scherer D, Dettmering D. Automated extraction of consistent time-variable water surfaces of lakes and reservoirs based on landsat and sentinel-2. Remote Sens. 2019; 11: 1010.

4. The distribution of water on, in, and above the Earth [Internet]. Reston, Virginia: USGS; 2020 [cited 2020 March 12]. Available from: https://www.usgs.gov/media/images/distributionwater-and-above-earth-0.

5. Singh A, Seitz F, Eicker A, Güntner A. Water budget analysis within the surrounding of prominent lakes and reservoirs from multi-sensor earth observation data and hydrological models: Case studies of the Aral Sea and Lake Mead. Remote Sens. 2016; 8: 953.

6. Liu Y, Yue H. Estimating the fluctuation of Lake Hulun, China, during 1975-2015 from satellite altimetry data. Environ Monit Assess. 2017; 189: 630. 
7. Gebrehiwot KA, Bedie AF, Gebrewahid MG, Hishe BK. Analysis of surface area fluctuation of the Haramaya Lake using remote sensing data. Momona Ethiopian J Sci. 2019; 11. doi: 10.4314/mejs.v11i1.9.

8. Shiklomanov Al, Lammers RB, Vörösmarty CJ. Widespread decline in hydrological monitoring threatens pan-Arctic research. EOS Trans Am Geophys Union. 2002; 83: 13-17.

9. Anyah RO, Forootan E, Awange JL, Khaki M. Understanding linkages between global climate indices and terrestrial water storage changes over Africa using GRACE products. Sci Total Environ. 2018; 635: 1405-1416.

10. Awange J, Hu KX, Khaki M. The newly merged satellite remotely sensed, gauge and reanalysisbased multi-source weighted-ensemble precipitation: Evaluation over Australia and Africa (1981-2016). Sci Total Environ. 2019; 670: 448-465.

11. Khaki M, Franssen HJ, Han S. Multi-mission satellite remote sensing data for improving land hydrological models via data assimilation. Sci Rep. 2020; 10: 1-23.

12. Verpoorter C, Kutser T, Seekell DA, Tranvik $\amalg$. A global inventory of lakes based on highresolution satellite imagery. Geophys Res Lett. 2014; 41: 6396-6402.

13. Khaki M, Forootan E, Sharifi MA, Awange J, Kuhn M. Improved gravity anomaly fields from retracked multimission satellite radar altimetry observations over the Persian Gulf and the Caspian Sea. Geophys J Int. 2015; 202: 1522-1534.

14. Sichangi AW, Makokha GO. Monitoring water depth, surface area and volume changes in Lake Victoria: Integrating the bathymetry map and remote sensing data during 1993-2016. Model Earth Syst Environ. 2017; 3: 533-538.

15. Zheng WZ, Zhan XW, Liu JC, Ek M. A preliminary assessment of the impact of assimilating satellite soil moisture data products on NCEP Global Forecast System. Adv Meteorol. 2018; 2018. doi: 10.1155/2018/7363194.

16. Awange J, Sharifi M, Baur O, Keller W, Featherstone W, Kuhn M. GRACE hydrological monitoring of Australia: Current limitations and future prospects. J Spat Sci. 2009; 54: 23-36.

17. Lettenmaier DP, Alsdorf D, Dozier J, Huffman GJ, Pan M, Wood EF. Inroads of remote sensing into hydrologic science during the WRR era. Water Resour Res. 2015; 51: 7309-7342.

18. Sheffield J, Wood EF, Pan M, Beck H, Coccia G, Serrat-Capdevila A, et al. Satellite remote sensing for water resources management: Potential for supporting sustainable development in datapoor regions. Water Resour Res. 2018; 54: 9724-9758.

19. Khaki M, Hoteit I, Kuhn M, Forootan E, Awange J. Assessing data assimilation frameworks for using multi-mission satellite products in a hydrological context. Sci Total Environ. 2019; 647: 1031-1043.

20. Li XH, Feng RT, Guan XB, Shen HF, Zhang LP. Remote sensing image mosaicking: Achievements and challenges. IEEE Geosci Remote Sens Mag. 2019; 7: 8-22.

21. Li XH, Wang LY, Cheng $Q$, Wu PH, Gan WX, Fang LN. Cloud removal in remote sensing images using nonnegative matrix factorization and error correction. ISPRS J Photogramm Remote Sens. 2019; 148: 103-113.

22. A landsat milestone: One hundred million downloads [Internet]. Reston, Virginia: USGS; 2020 [cited 2020 March 10]. Available from: https://www.usgs.gov/center-news/a-landsatmilestone-one-hundred-million-downloads?qt-news science products=1-qtnews science products. 
23. Zeinelabdeina KA, Albiely Al. Ratio image processing techniques: A prospecting tool for mineral deposits, Red Sea Hills, NE Sudan. Int Arch Photogramm Remote Sens Spat Inf Sci. 2008; 37: 1295-1298.

24. Ding F. Study on information extraction of water body with a new water index (NWI). Sci Surv Mapp. 2009; 34: 155-157.

25. Ali E, Khidir SE, Babikir IA, Abdelrahman EM. Landsat ETM+ 7 digital image processing techniques for lithological and structural lineament enhancement: Case study around Abidiya Area, Sudan. Open Remote Sens J. 2012; 5: 83-89.

26. Candra DS, Phinn S, Scarth P. Cloud and cloud shadow removal of landsat 8 images using Multitemporal Cloud Removal method. Proceedings of the 6th International Conference On Agro-Geoinformatics; 2017 August 7-10; Fairfax, VA, USA. New York: IEEE.

27. Mwaniki M, Kuria DN, Boitt M, Ngigi T. Image enhancements of Landsat 8 (OLI) and SAR data for preliminary landslide identification and mapping applied to the central region of Kenya. Geomorphology. 2017; 282: 162-175.

28. Li HY, Mao DH, Li XY, Wang ZM, Wang CZ. Monitoring 40-year lake area changes of the Qaidam Basin, Tibetan Plateau, using Landsat time series. Remote Sens. 2019; 11: 343.

29. Yuan YT, Fang FM, Zhang GX. Superpixel-based seamless image stitching for UAV images. IEEE Trans Geosci Remote Sens. 2021; 59: 1565-1576.

30. Gao BC. NDWI-A normalized difference water index for remote sensing of vegetation liquid water from space. Remote Sens Environ. 1996; 58: 257-266.

31. Xu HQ. Modification of normalised difference water index (NDWI) to enhance open water features in remotely sensed imagery. Int J Remote Sens. 2006; 27: 3025-3033.

32. Holdren GC, Turner K. Characteristics of lake mead, Arizona-Nevada. Lake Reserv Manag. 2010; 26: 230-239.

33. Beaver JR, Kirsch JE, Tausz CE, Samples EE, Renicker TR, Scotese KC, et al. Long-term trends in seasonal plankton dynamics in Lake Mead (Nevada-Arizona, USA) and implications for climate change. Hydrobiologia. 2018; 822: 85-109.

34. Rosen MR, Turner K, Goodbred SL, Miller JM. A synthesis of aquatic science for management of Lakes Mead and Mohave. Reston, VA, USA: US Geological Survey; 2012; 1381.

35. Avalos-cueva D, Filonov A, Tereshchenko I, Monzón CO, Velázquez-muñoz FÁ. Thermal structure and circulation in Lake Chapala, Mexico. J Limnol. 2016; 75: 137-143.

36. Cueva DA, Monzón CO, Filonov A, Tereshchenko I, Covarrubias PL, González JR. Natural frequencies of seiches in Lake Chapala. Sci Rep. 2019; 9: 1-11.

37. Bryant R, Moran MS, McElroy S, Holifield C, Thome K, Miura T. Data continuity of Landsat-4 TM, Landsat-5 TM, Landsat-7 ETM+, and Advanced Land Imager (ALI) sensors. Proceedings of the IEEE International Geoscience and Remote Sensing Symposium; 2002 June 24-28; Toronto, ON, Canada.

38. Landsat satellite missions [Internet]. Reston, Virginia: USGS; 2020 [cited 2020 June 19]. Available from: https://www.usgs.gov/land-resources/nli/landsat/landsat-satellitemissions?qt-science support page related con=2-qt-science support page related con.

39. Schwatke C, Dettmering D, Seitz F. Volume variations of small inland water bodies from a combination of satellite altimetry and optical imagery. Remote Sens. 2020; 12: 1606.

40. Bhagwat T, Klein I, Huth J, Leinenkugel P. Volumetric analysis of reservoirs in drought-prone areas using remote sensing products. Remote Sens. 2019; 11: 1974. 
41. Schwatke C, Dettmering D, Bosch W, Seitz F. DAHITI-an innovative approach for estimating water level time series over inland waters using multi-mission satellite altimetry. Hydrol Earth Syst Sci. 2015; 19: 4345-4364.

42. Object detection in a cluttered scene using point feature matching [Internet]. Natick, Massachusetts, USA: MathWorks; 2020 [cited 2020 March 23]. Available from: https://www.mathworks.com/help/vision/examples/object-detection-in-a-cluttered-sceneusing-point-feature-matching.html.

43. Stoica P, Moses RL. Spectral analysis of signals. Upper Saddle River, NJ: Prentice Hall; 2005.

44. World of change: Water level in lake powell [Internet]. NASA Earth Observations; 2020 [cited 2020 June 15]. Available from: https://earthobservatory.nasa.gov/world-ofchange/LakePowell.

45. Molden D. Water for food, water for life: A comprehensive assessment of water management in agriculture. London, UK: Earthscan; 2007.

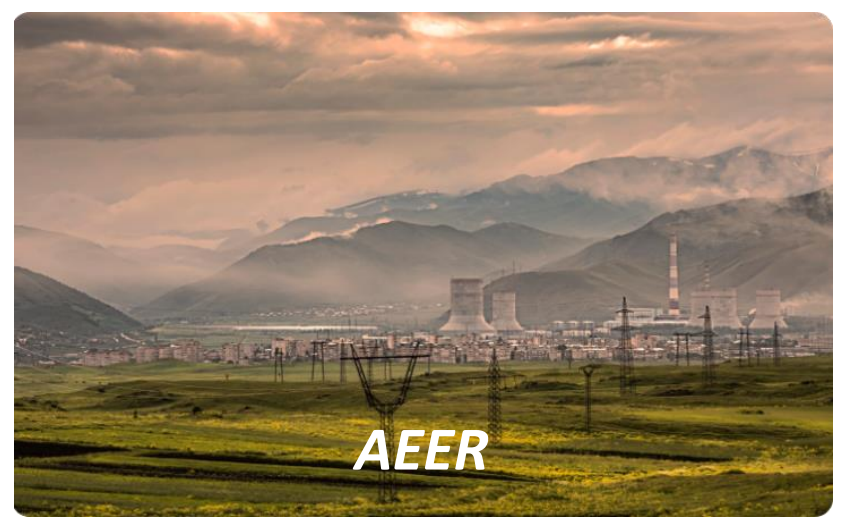

Enjoy $A E E R$ by:

1. Submitting a manuscript

2. Joining in volunteer reviewer bank

3. Joining Editorial Board

4. Guest editing a special issue

For more details, please visit:

http://www.lidsen.com/journals/aeer 